\title{
Possible evaporite karst in an interior layered deposit in Juventae Chasma, Mars
}

\author{
Davide Baioni* and Mario Tramontana \\ Planetary Geology Research Group, Dipartimento di Scienze Pure e Applicate (DiSPeA), Università degli Studi di Urbino "Carlo Bo", \\ Campus Scientifico Enrico Mattei, 61029 Urbino (PU), Italy
}

\begin{abstract}
This paper describes karst landforms observed in an interior layered deposit (ILD) located within Juventae Chasma a trough of the Valles Marineris, a rift system that belongs to the Tharsis region of Mars. The ILD investigated is characterized by spectral signatures of kieserite, an evaporitic mineral present on Earth. A morphologic and morphometric survey of the ILD surface performed on data of the Orbiter High Resolution Imaging Science Experiment (HiRISE) highlighted the presence of depressions of various shapes and sizes. These landforms interpreted as dolines resemble similar karst landforms on Earth and in other regions of Mars. The observed karst landforms suggest the presence of liquid water, probably due to ice melting, in the Amazonian age.
\end{abstract}

Keywords: $\quad$ Mars, interior layered deposits, karst, climate change

Received 21 Octomber 2016; Revised 18 April 2017; Accepted 19 April 2017

Citation: Baioni D. and Tramontana M., 2017. Possible evaporite karst in an interior layered deposit in Juventae Chasma, Mars. International Journal of Speleology, 46 (2), 181-189. Tampa, FL (USA) ISSN 0392-6672 https://doi.org/10.5038/1827-806X.46.2.2085

\section{INTRODUCTION}

The existence of karst-like topographies and karst processes have been hypothesized in many regions of the Martian surface since high-resolution images of Viking Orbiter first became available (Schaeffer, 1990; Peulvast \& Masson, 1993; Costard \& Kargel, 1995; Kargel et al., 2004; Wyrick et al., 2004; Preuschmann et al., 2006). The presence of soluble evaporite minerals on Mars confirmed by data from the OMEGA instrument on Mars Express (Bibring et al., 2006), the Compact Reconnaissance Imaging Spectrometer for Mars instrument (Murchie et al., 2007) on the Mars Reconnaissance Orbiter (MRO), and the Mars Exploration Rovers, supported the possible development of evaporite karst features and the development of karstic terrains with associated caves (Boston, 2004).

Recent works based on new high-resolution images demonstrate the presence of karst landforms such as doline depressions in several Martian evaporite deposits (Baioni et al., 2009; Baioni \& Wezel, 2010; Grindrod \& Balme, 2010; Jackson et al., 2011; Flahaut et al., 2015), highlighting the usefulness of karst landforms as lithological, stratigraphic and paleoclimatic markers (Baioni \& Sgavetti, 2013; Baioni \& Tramontana, 2015).

Juventae Chasma, is a deep closed depression centered near $4^{\circ} \mathrm{S}, 61^{\circ} \mathrm{W}$ and approximately $500 \mathrm{~km}$ north of Valles Marineris (Catling et al., 2006). Here, four main large interior layered deposits (ILDs) located close to the foot of the western wall of the chasma have been previously identified and studied (Chapman et al., 2003; Catling et al., 2006; Kuzmin et al., 2009; Noel et al., 2015). These ILDs consist of sedimentary rocks mainly composed of kieserite $\left(\mathrm{MgSO}_{4} \cdot \mathrm{H}_{2} \mathrm{O}\right)$ (Kuzmin et al., 2009; Noel et al., 2015) an evaporitic mineral that can also be found on Earth. The largest ILD is located in the central part of the chasma and is characterized by weathered surface flanks (Noel et al., 2015), and by the widespread presence of shallow depressions, of unknown origin, displaying different shapes and sizes. The goal of this study is to describe, for the first time, these depressions, and discuss their possible origins and paleoclimatic significance.

\section{STUDY AREA}

Juventae Chasma is about $270 \mathrm{~km}$ long in the north-south direction and about $185 \mathrm{~km}$ across at its widest point in its southern portion. The lowest point of the floor of Juventae Chasma lies $4.4 \mathrm{~km}$ below the topographic datum and the depression becomes shallower toward the northern end where it opens into Maja Vallis outflow channel (Catling et al., 2006; Noel et al., 2015).

The geology of Juventae Chasma (Fig. 2) can be divided into five geomorphic units (Catling et al., 

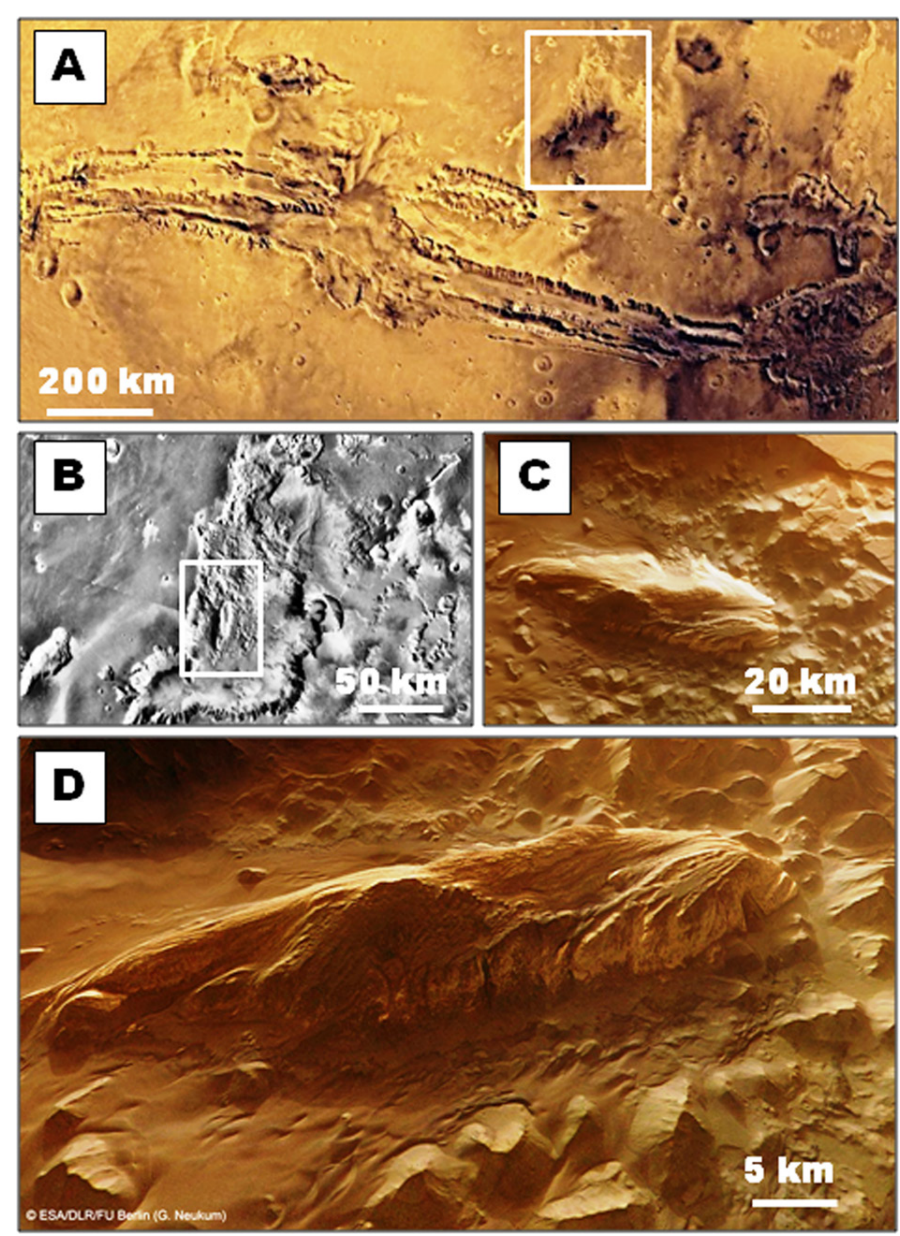

Fig. 1. A) Valles Marineris system Mars, with the location of Juventae Chasma (white box). Image NASA/USGS/ESA/DLR/FU Berlin (G. Neukum) (www.google.com/mars); B) Aerial view of Juventae Chasma with the location of investigated the kieserite ILD (white box). Mars Digital Image Map version 2.1 (https://www.google.com/ mars/); C) Aerial image of the kieserite ILD located within Juventae Chasma (Image taken by the high-resolution stereo camera on ESA's Mars Express, (http://www.esa.int/spaceinimages//mages/2013/12/ Juventae Chasma; north toward right); D) Close-up perspective view image of the kieserite ILD(Image taken by the high-resolution stereo camera on ESA's Mars Express, http://www.esa.int/spaceinimages/ Images/2013/12/Juventae_Chasma_perspective; north toward right).

2006) represented by the plateau, wall rock, sand sheets, chaotic terrain and ILDs. The plateau unit that surrounds the chasma is comprised primarily of basaltic lava flows (Catling et al., 2006). The wall rock unit can be divided into an upper part of dark material interpreted as volcanic layering, and a lower part characterized by ridges and troughs on eroded poorly graded fine and coarse materials (Noel et al., 2015). The sand sheets unit is represented by coarsegrained dark sands that form the bulk of the southern chasma floor. The chaotic terrain unit consists of a jumble of large angular blocks, cones and plateaus, extending from the center to the northern part of the chasma (Noel et al., 2015).

The ILDs consist of sedimentary rocks displaying mound morphologies, covered with sand dust, of varying thickness ranging between 1,700 and 2,900 m (Noel et al., 2015). Four major ILDs (area $>50$ km²) have been observed in previous studies (Catling et al., 2006; Kuzmin et al., 2009; Noel et al., 2015). They exhibit a variety of surface morphologies such as fine layer structure down to $10 \mathrm{~m}$ scale, cuspate sculpted ridges, bench and cliff structures at $100 \mathrm{~m}$ horizontal scale and cliffs that are associated with intermediate-toned debris aprons (Catling et al., 2006). All the ILDs exhibit light-toned surfaces that are brighter than nearby dust, sand and rock. They display generally high values of thermal inertia that support the hypothesis that these units consist of sedimentary rock covered with a variably thick layer of sand and/or dust (Catling et al., 2006). The mineralogical characteristics of the ILDs in Juventae Chasma have previously been determined by spectrometer data analysis as sulfate deposits (Catling et al., 2006). Further spectral studies revealed a suite of mono- and polyhydrated sulfate minerals, displaying mainly clear signatures of kieserite (Kuzmin et al., 2009; Noel et al., 2015). These deposits are thought to be formed as evaporites from a large sea or lake that existed in the Noachian or early Hesperian prior to the development of Juventae Chasma. Alternatively, they are thought to be built up by dry deposition of volcanic sulfate aerosols, most likely in association with the deposition of low latitude snow/ice containing sulfate-rich aerosols during ancient obliquity cycles. In fact, the data provided by Catling et al. (2006) are consistent with either occurrences of lacustrine or airborne deposition over an extended period of time prior to the emplacement of Hesperian lava flows on the plateau above the chasm. The ILDs have been exhumated from the surrounding units (Catling et al., 2006).

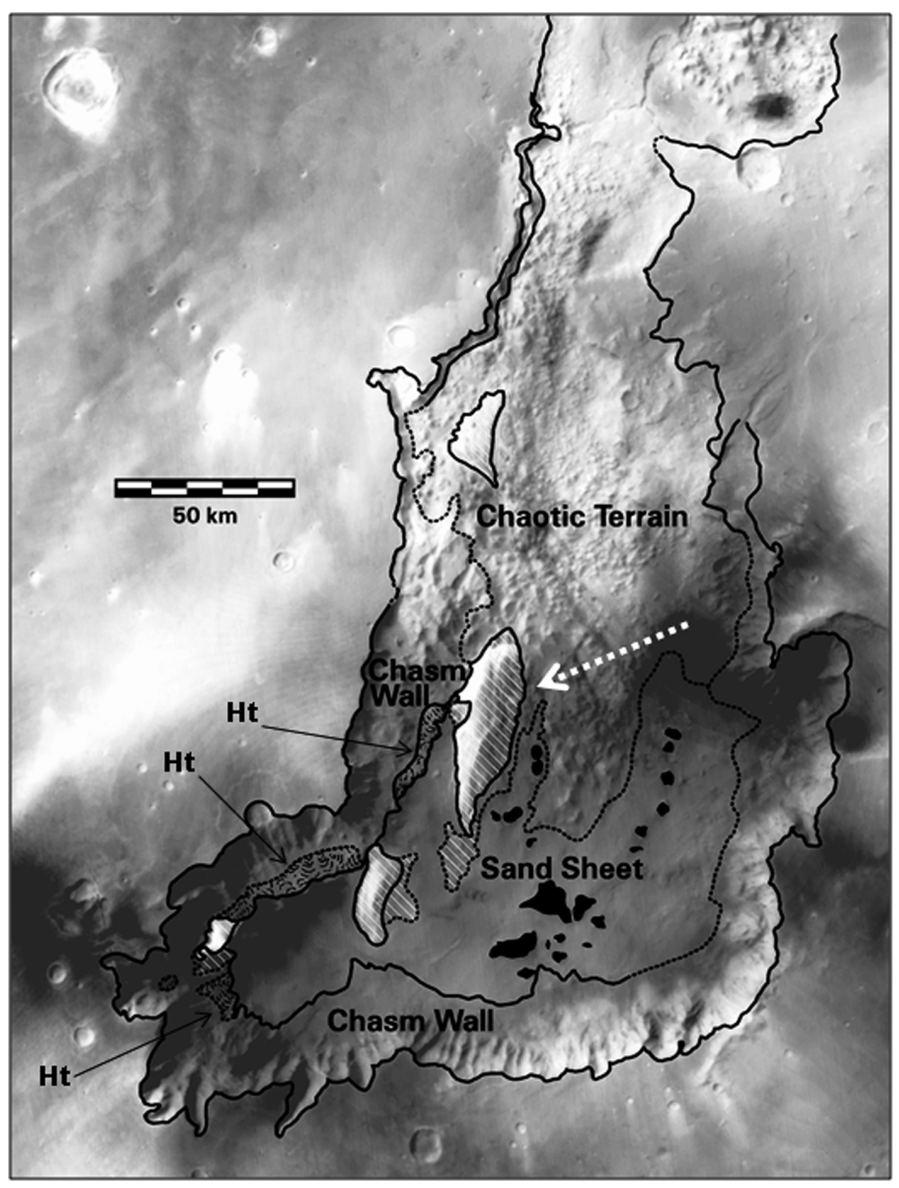

Fig. 2. Geological map of Juventae chasma (modified by Catling et al., 2006). The five geomorphic units are (1) sand sheet, (2) chaotic terrain, (3) light-toned layered deposits (cross-hatched), (4) chasma wall material and (5) hummoky terrain ( $\mathrm{Ht}$ ) (black arrows). The investigated ILD is indicate witrh the white dashed arrow. Solid black polygons represents rocky blocks found within the sand sheet unit. 
We focused our investigation on the largest and highest of the ILDs located in the central part of the chasma (Fig. 1). This sulfate mound is $53 \mathrm{~km}$ long and $20 \mathrm{~km}$ wide, its summit lies at $257 \mathrm{~m}$ above the standard Mars datum, while the lowest base lies at about $-3 \mathrm{~km}$, thus its total height is about 3,300 m (Catling et al., 2006). On the ILD, material covering part of the surface forms thick dark capping layers associated with dunes. These dunes stretch downwind (southward) from the apparent source material (Catling et al., 2006). The top of the mound is characterized by ridges and valleys, and displays dark sand deposits (Noel et al., 2015). A few small impact craters can be observed in the capping layers, while they are almost entirely absent elsewhere on the ILDs surface. The flanks have a very rough, weathered surface texture, appear finely layered with strata of an average thickness of $3.2 \mathrm{~m}$ (Novakovic et al., 2013) and display widespread shallow depressions of unknown origin with different sizes and shapes.

\section{METHODS}

Landform features were investigated through an integrated visual analysis of data from the Mars Reconnaissance Orbiter (MRO) High-Resolution Imaging Science Experiment (HiRISE) (McEven et al., 2007) and the Context Camera (CTX) (Malin et al., 2007).

Analysed CTX images (B18_016646_1763_ XN_03S061W; G01_018624_1764_XN_03S061W; J01_045208_1765_XN_03S061W; T01_000875_1765_ XI_03S061W) have a spatial resolution of $6 \mathrm{~m} /$ pixel. Analysed HiRISE images (ESP_016712_1760; PSP_007060_1760; ESP_018624_1765; PSP_002946_ 1765) have a spatial resolution ranging between 25 and $27.8 \mathrm{~cm}$ per pixel (objects between 80 and $84 \mathrm{~cm}$ across are resolved). HiRISE images (including enhanced RGB, IRB, and derived stereoanaglyph images) give enough detail to observe even small characteristics of the landforms.

\section{MORPHOLOGICAL ANALYSIS OF THE ILD FEATURES}

The morphological analysis carried out revealed the presence of closed, shallow, rimless depressions of various sizes, surrounded by unbroken plains. Their locations and shapes appear to be unrelated to tectonic lineaments (i.e., joints, faults) and their random distribution generally did not display any particular pattern of orientation. The depressions are located mainly in the flat areas on the top of the ILDs and along sectors of their flanks with a gentle slope.

Depressions display various plan forms, ranging from rounded (Fig. 3A-D) to elliptical (Fig. 3E ), droplike (Fig. 3B ), irregular (Fig. 4C $-4 \mathrm{E}$ ) or narrow and elongate (Fig. 3A, B). The depression lengths (L), (defined as the long axes confined by the outermost closed contour of the depression), range from $77 \mathrm{~m}$ to $130 \mathrm{~m}$ for rounded and elliptical shapes, from 190 to more than $210 \mathrm{~m}$ for irregular shapes, and from 665 $\mathrm{m}$ to more than $1,000 \mathrm{~m}$ for elongate shapes. Widths
(W) generally range from 30 to $69 \mathrm{~m}$ for rounded and elliptical shapes, from 72 to $85 \mathrm{~m}$ for irregular shapes, and from $130 \mathrm{~m}$ to $145 \mathrm{~m}$ for elongate shapes.

The major axes have very different orientations $(\mathrm{N}-\mathrm{S}, \mathrm{NE}-\mathrm{SW}, \mathrm{NW}-\mathrm{SE}$ and E-W) that are unrelated to depression locations and shapes.

Depressions generally display well-defined, continuous and sharp margins, while their sides exhibit both symmetrical (Fig. 3A, D, E; 4A, B) and asymmetrical (Fig. 3B; 4D, E), very steep (Fig. 3A, B; 3E, D) to almost vertical (Fig. 4A, B; 4D, E) slopes. The sides generally display slope processes such as: accumulation of deposits at the base of the slopes (Fig. 3A, B; 4E, D), debris on the floor of a few depressions (Fig. 4A), and stepped or terraced slope morphologies (Fig. 4A, B; 4E).

The floors appear flat showing dark sediment and/or dust accumulation generally displaying well developed systems of dune morphologies (Fig. 3E; $4 \mathrm{~A}, \mathrm{~B} ; 4 \mathrm{D}, \mathrm{E})$ and in a few cases the presence of superimposed impact craters of small size (Fig. 3B; 4D, E).

The main parameters used in the morphometric analysis of karst depressions on Earth (Bondesan et al., 1992) such as the area (A), perimeter (P), elongation index (Ei), and circularity index (Ci) were calculated.

The perimeter length $(\mathrm{P})$, calculated on the contour of the depressions, ranges from $194 \mathrm{~m}$ to more than $2,500 \mathrm{~m}$, while the Area (A) of the depressions, calculated as the measurement of the planimetric surface bordered by the perimeter, ranges from 1,900 $\mathrm{m}^{2}$ to more than $15,000 \mathrm{~m}^{2}$.
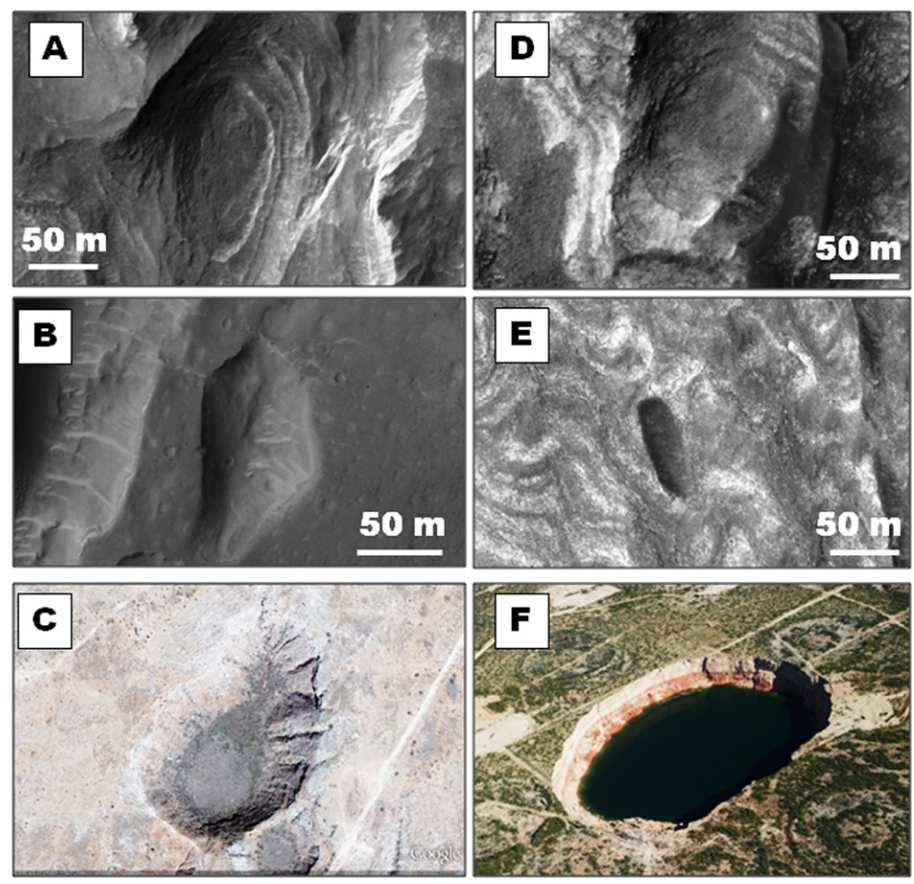

Fig. 3. A) Rounded doline displaying steep sides and flat bottom. Image HiRISE ESP_027195_1765 (north toward up); B) Drop-like shaped doline displaying steep sides and flat bottom. Image HiRISE ESP_027195_1765 (north toward up); C) Doline in the evaporite terrain of New Mexico (U.S.A.) (www.earth.google.com); D) Rounded and bowl shaped doline displaying flat bottom. Image HiRISE PSP_00760_1760 (north toward up); E) Elliptical doline displaying steep sides and flat bottom. Image HiRISE PSP_002590_1765 (north toward up); F) Doline in the evaporite terrain of Texas (U.S.A.). ( http://www. beg.utexas.edu/research/ programs/near-surface-observatory/wink-sink). 


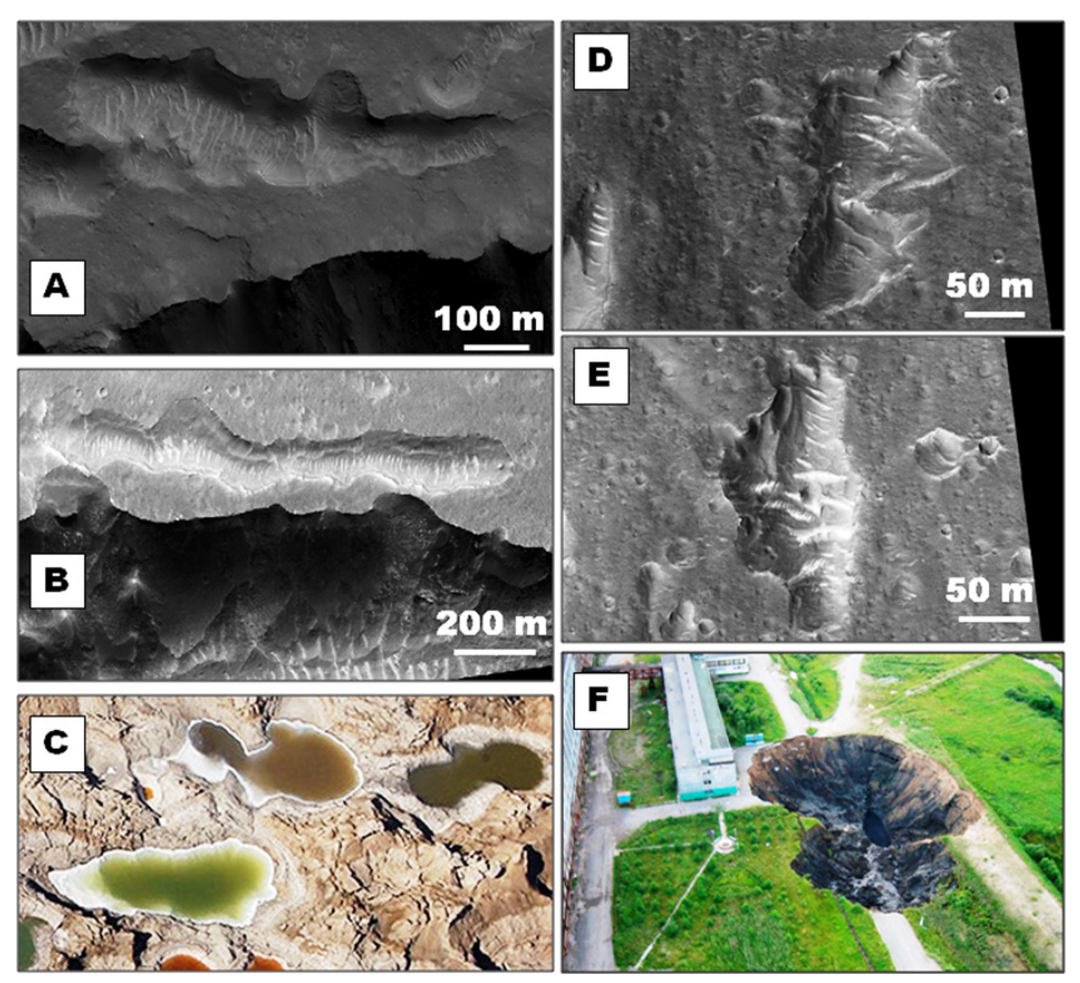

Fig. 4. A) Elongate doline displaying vertical sides and flat bottom. Image HiRISE ESP 0276831765 (north toward right); B) Elongate and narrow doline displaying vertical sides and flat bottom. Image HiRISE ESP_027683_1765 (north toward right);. C) Aerial view of elongate doline in the Dead Sea region. Image (modified) from https://au.news.yahoo.com/world/a/26734580/nature-s-revenge-on-banks-ofdead-sea; D) Irregular shaped doline displaying vertical sides and flat bottom. Image HIRISE 002590_1765 (north toward up); E) Irregular shaped doline displaying steep sides and flat bottom. Image HiRISE 002590_1765 (north toward up); F) Doline in the evaporite terrain in the Urals region, Russia. (http://siberiantimes.com/other/ others/news/n0227-sinkhole-gets-bigger-in-city-plagued-by-giant-craters)

The elongation index, expressed as the ratio between the longest axis and the perpendicular width $(\mathrm{L} / \mathrm{W})$ was calculated. The depressions have very different elongation index values. Rounded and elliptical shapes have values which range from 1.6 to 2.5 , irregular shapes have values ranging between 2.3 to 3.0, while the values for elongated shapes range from 5.0 to more than 8.0. Finally, the circularity index (ratio between the measured depression area and the area of a circle with the same perimeter) ranged between 0.1 and 0.7 .

\section{DISCUSSION}

Interpretation of the karst origin of the depressions

Based on a detailed analysis of the characteristics of the features described above, we interpreted these morphologies as karst depressions. The morphologies were specifically interpreted as dolines of polygenetic origin (Ford \& Williams, 2007). The landforms appear to have formed as a result of the dissolution of rocks and downward percolation of seepage water highlighting major contributions of karst processes, because they lacked evidence of wind action or erosional features (i.e., slope processes, parabolic or super-parabolic cross-section) associated with the evolution of impact craters.

Moreover, the studied landforms display morphological convergence with terrestrial dolines and their formation process is thought to be analogous to the development of similar landforms in evaporite rocks on Earth, where the presence of dolines, as a karst landform index (Ford \& Williams, 2007; Gutiérrez et al., 2008; De Waele et al., 2009, 2011), indicates intense surface dissolution and runoff along the whole area. The landforms have morphometric (size) and morphologic (shape) similarities with terrestrial dolines that commonly develop in all kinds of evaporite or limestone terrains on Earth (see Table 1) (Johnson, 1997; Ford, 1998; Ferrarese et al., 2002; Cucchi \& Zini, 2003; Gutièrrez et al., 2008; Galve et al., 2009; Di Maggio et al., 2012), such as those in New Mexico (Fig. 3C), Texas (Fig. 3F), the Dead Sea (Fig. 4C), and Russia (Fig. 4F). Additionally, they display strong morphological convergence with the evaporite dolines described in other regions of Mars, such as Tithonium Chasma (Baioni et al., 2009; Baioni \& Wezel, 2010; Baioni 2013), Coprates Chasma (Baioni et al., 2011), Hebes Chasma (Grindrod \& Balme, 2010; Jackson et al., 2011), Sinus Meridiani (Baioni \& Sgavetti, 2013; Baioni et al., 2014; Flahaut et al., 2015), Iani Chaos (Baioni \& Tramontana, 2015) and other regions (McKey \& Nedell, 1998; Schaeffer, 1990; Spencer \& Fanale, 1990).

\section{Alternative formation hypotheses \\ Aeolian processes}

Observed depressions were not created by wind action. They lack a preferential orientation, which rules out formation by wind deflation. Orientations of the major axes of the depressions showed different peaks, in directions ranging from N-S to E-W, NE-SW to NW-SE and ENE-WSW to NNW-SSE. Thus, this hypothesis can be ruled out.

On Earth, depressions shaped by wind action, called blowouts, appear as bowl-shaped hollows caused by slight deflation of the depressions (Neuendorf et al., 2006). Blowouts are elongated along the direction of the wind flow, display generally elliptical shapes and have arcuate sides. Sediment accumulation is thicker at the foot of the wall facing the wind. On Mars, blowouts have been found only in Chryse Planitia and Elysium Planitia (Kuznetsov et al., 2005), where they are located within impact craters and often have distinct rims. When a crater contains several depressions, the depressions are organised in overlapping chains (Kuznetsov et al., 2005). The observed depressions in Juventae Chasma have completely different features from those normally created by wind action.

\section{Impact craters}

Features of the observed depressions did not support their formation as eroded or softened impact craters, as indicated by two lines of evidence. Firstly, the depressions displayed various plan forms, such as lobate, elongate, drop-like and polygonal shapes, that cannot be created by impacts. An impact would create bowl-shaped depressions characterized by a circular plan form (Robbins \& Hyneck, 2012). Secondly, 
Table 1. Summary of morphometric and morphological characteristics of karst depressions on Earth and other regions of Mars compared to those in the ILDs in Juventae Chasma.

\begin{tabular}{|l|c|c|c|c|c|}
\hline \multicolumn{1}{|c|}{ Location } & Area $\mathbf{( m}^{\mathbf{2}} \mathbf{n}$ & \multicolumn{1}{c|}{ Shape } & Circularity Index & $\begin{array}{c}\text { Elongation } \\
\text { Index }\end{array}$ & References \\
\hline Juventae Chasma & $280 \rightarrow 435,000$ & rounded to elongated & $0.11-0.69$ & $1.62 \leq 8.00$ & This work \\
\hline Tyrrhena Terra & $300 \rightarrow 10,000$ & rounded to elongated & $0.60-0.82$ & $1.05-2.65$ & $\begin{array}{c}\text { Baioni \& } \\
\text { Tramontana, 2016 }\end{array}$ \\
\hline Iani Chaos & $600 \rightarrow 9,000$ & rounded to elongated & $0.57-0.88$ & $1.10-2.80$ & $\begin{array}{c}\text { Baioni \& } \\
\text { Tramontana, } 2015\end{array}$ \\
\hline Hungary & $68 \rightarrow 250,000$ & rounded to elongated & $0.29-0.99$ & $1.00-6.22$ & Telbisz et al., 2016 \\
\hline U.S.A. & $75 \rightarrow 5,000,000$ & rounded to elongated & $0.15-0.95$ & $1.62-1.99$ & $\begin{array}{c}\text { Denizman, 2003; } \\
\text { Brinkmann et al., 2008 }\end{array}$ \\
\hline Spain & $700 \rightarrow 2,450,000$ & rounded to elongated & $0.22-0.57$ & $0.63-1.37$ & $\begin{array}{c}\text { Lòpez-Vicente } \\
\text { et al., 2009 }\end{array}$ \\
\hline
\end{tabular}

all the observed depressions lack raised rims and ejecta. It is unlikely that all possible rims and ejecta deposits were totally destroyed or cancelled by erosion processes. Several authors have investigated changes in Martian crater morphology in the advanced stage of modification due to erosion processes (Craddock et al., 1997; Forsberg-Taylor et al., 2004). When rims are removed completely through erosion and back-wasting processes, the crater fills with a deposit having a parabolic or super-parabolic cross-section (ForsbergTaylor et al., 2004), and the crater walls show a decrease of their average interior slope (Craddock et al., 2008). In contrast, the depressions observed here do not display these features, but are characterized by smaller, flat floors and steep or vertical walls.

Ring-mould craters (RMC) have unusual morphologies that have been identified only on lineated valleys, lobate debris aprons and concentric craters in the northern and southern mid-latitudes of Mars. RMCs are generally rimless and consist of an outer annular trough surrounding various interior morphologies (e.g., central pit, tabular plateau, bowl with central peak, bowl with tabular plateau and double bowl) (Kress \& Head, 2008). The depressions observed here do not display any of these features.

\section{Volcanic processes}

Landform formation by volcanic processes can be ruled out, due to the absence of any volcanic morphology in this part of the chasma. Pit craters associated to volcanic activity can occur within collapsed magma chambers or along lava tubes where they are arranged in linear arrays (Soare et al., 2007). In contrast, the observed depressions do not follow any particular pattern of orientation.

\section{Tectonics}

Pit craters due to tectonic processes occur within graben systems or near areas having extensional features, such as fault lines (Soare et al., 2007), and linear arrays of circular to elliptical depressions. These features do not characterize the area investigated in this study, and the depressions do not follow any orientation or circular pattern, ruling out this hypothesis.

\section{Groundwater sapping}

Formation of depressions through groundwaterrelated processes, in which subsurface water breaches the surface during occasional upwelling events, can be ruled out since the studied morphological features lacks outflow channels and are surrounded entirely by unbroken plains. Groundwater sapping processes imply very high erosion rates and the removal of huge amounts of material, so as to achieve the present configuration of the depressions. To shape these depressions, the water flow would generate deep and wide outflow channels. Moreover, the eroded material would need to be deposited somewhere on the floor, but such deposits are absent in the investigated areas.

The formation of depressions through melting processes driven by hydrothermal activity can be ruled out by the morphology of the surrounding terrain. Geothermal melting within permafrost produces a substantial amount of water close to the surface, which may erupt out of the ground (Ogawa et al., 2003). Such an eruptive flow event would catastrophically release subsurface water causing collapse and disruption of the overlying surface. This would lead to outflow channels and chaotic terrains (Ogawa et al., 2003; El Maarry et al., 2012) that were not observed in the investigated area.

\section{Thermokarst}

The thermokarst origin can be ruled out in this study due to the morphological features of the depressions and the surrounding terrain. On Mars, unsorted and small-sized polygons are often associated with thermokarst depressions (Soare et al., 2014) and are diagnostic features of periglacial activity (Mellon et al., 2014). Landscape evolution modelling of Martian sublimation thermokarst (Dundas et al., 2015) demonstrated that thermokarst depressions show scallop-like morphologies where the warm equator-facing slope retreats and becomes shallower much faster than the pole-facing scarp. Moreover, thermokarst depressions on Mars also exhibit newly dessicated regolith dotted with small surficial pockmarks and pits. Instead, depressions observed in this study did not show any sublimation pits, pockmarks or unsorted and small-sized polygons, nor did they show a marked difference in the oppositefacing slope. Finally, the morphology of the surrounding terrain lacks any feature that could be ascribed to periglacial activity. In fact, morphologies suggesting ice sublimation such as small pits and small, unsorted polygons, are absent in the whole area. 


\section{Compaction of unconsolidated sediments}

The morphologies of the depressions can rule out their formation through compaction of unconsolidated sediments. In fact, the compaction of unconsolidated sediments because of the features of material involved, usually does not produce depressions characterized by vertical or very steep sides (Cooper, 1989; Martinez \& Boehner, 1996; Cooper \& Waltham, 1999) as can be observed for theinvestigated depressions.

\section{Possible morphogenesis of the observed landforms}

The studied landform features appear to reflect ice- and/or water-related processes. In our opinion, the landforms provide compelling evidence of the existence of liquid water because they seem to be formed by dissolution processes. The development of landforms related to liquid water on Mars could have been triggered by the melting of ice and/or snow, and/or permafrost, or alternatively by the structural delivery of water to the surface. The study area lacks morphological features and topography that would suggest the presence of sapping processes due to structural control. Therefore, the melting of ice or snow could have driven the processes of dissolution or collapse on the evaporite rock. This process would be the same of what happens on ice-covered terrains on Earth. Hence, the melting of ice or snow would provide the water necessary for the dissolution and collapse processes, as already proposed for the karst landforms found in other regions of Mars, such as Sinus Meridiani (Baioni \& Sgavetti, 2013; Flahaut et al., 2015), Tithonium Chasma (Baioni et al., 2009; Baioni \& Wezel, 2010; Wezel \& Baioni, 2010; Baioni, 2013), Coprates Chasma (Baioni et al., 2011), Hebes Casma (Grindrod \& Balme, 2010; Jackson et al., 2011) and Tyrrhena Terra (Baioni \& Tramontana, 2016), as well as in karst terrains of Canada, the United States, Russia and the high mountain regions of Europe.

On Earth, evaporite karst develops much more rapidly than on carbonate rock because of the higher solubility of the evaporite rocks (Johnson, 2008), but are also quickly destroyed by subsequent wet episodes (Klimchouk, 2004). Thus, considering the characteristics of evaporite karst and its rapid evolution, the observed landforms seem to have been affected by only one geological episode with available liquid water. After this formation episode, there was no more water available, and the karstification processes ended.

Moreover, the features of the depressions such as, the presence of gravitational slope processes and stepped or terraced morphologies along their sides, accumulation deposits on the floors, and several superimposed impact craters (Figs. 3B; 4D, E), suggest that they are not very young from the erosional point of view. Considering that the ILDs are thought to be of Hesperian age (Catling et al., 2006), the karst landforms observed must be younger than the ILDs on which they are shaped. Taken together, these data illustrate that the observed karst landforms are probably of middle Amazonian age.

\section{Climate and karst}

The landform features provide evidence of waterrelated processes because the availability of water is the key climatic factor in karst development (Ford \& Williams, 2007). Liquid water was probably derived from the melting of ice-rich ground or snow that would have developed due to episodic changes of Martian obliquity (Laskar et al., 2004; Madeleine et al., 2009; Pacifici et al., 2009).

Theoretical considerations about the stability of water ice and numerical simulations of climate predicted that areas of surface ice or snow accumulation may have shifted repeatedly between polar, middle, tropical and equatorial latitudes in response to changes in Martian orbital parameters and atmospheric physical characteristics in the past (Madeleine et al., 2009; Wordsworth et al., 2013).

Studies have found evidence of near-surface ice in Martian tropical regions, as well as ground ice features near or at the equator (Hynek, 2009; Shean, 2010; De Blasio, 2011; Gourronc et al., 2014).

The ice/snow melt caused by climatic change probably occurred gradually and over a sufficiently long time to shape the karst landforms.

\section{SUMMARY}

The analysis carried out in this study suggests that: i) The morphological characteristics of the investigated depressions found in the Juventae Chasma ILDs best fit with karst landforms on Mars and Earth, whereas any other origin can be discarded; (ii) Due to their high solubility, evaporite karst on Earth forms in a very short time and generally is rapidly destroyed by subsequent wet episodes (Klimchouk, 2004). However, karst landform characteristics on Mars suggest that the landforms were more likely affected by a single geologic 'wet episode', characterized by a period of sufficient water availability caused by melting of ice, followed by dry climate conditions, enabling these forms to survive; (iii) The karst landforms suggest a response to climatic change, because they require the presence of sufficient water for their development. Hence our findings, being diagnostic of liquid water shaping Hesperian ILDs, suggest that climatic change occurred in the tropical regions during the Amazonian period.

\section{REFERENCES}

Baioni D., Zupan Hajna N. \& Wezel F.C., 2009 - Karst landforms in a martian evaporitic dome. Acta Carsologica, 38 (1): 9-18. https://doi.org/10.3986/ac.v38i1.132

Baioni D. \& Wezel F.C., 2010 - Morphology and origin of an evaporite dome in Tithonium chasma, Mars. Planetary and Space Science, 58: 847-857. https://doi.org/10.1016/j.pss.2010.01.009

Baioni D., Zupan Hajna N. \& Wezel F.C., 2011 - Karst landforms in an interior layered deposit within the Coprates chasma, Mars. Acta Carsologica, 40 (3): 473481. https://doi.org/10.3986/ac.v40i3.59

Baioni D., 2013 - Morphology and geology of an interior layered deposit in the western Tithonium Chasma, Mars. Planetary and Space Science, 89: 140-150. https://doi.org/10.1016/j.pss.2013.09.019 
Baioni D. \& Sgavetti M., 2013 - Karst terrains as possible lithologic and stratigraphic markers in northern Sinus Meridiani, Mars. Planetary and Space Science, 75: 173-181.

https://doi.org/10.1016/j.pss.2012.08.011

Baioni D., Murana A. \& Zupan Hajna N., 2014 Karstic morphology in northern Sinus Meridiani, Mars. Geoscience Journal, 18 (3): 261-268.

https://doi.org/10.1007/s12303-014-0003-0

Baioni D. \& Tramontana M. 2015 - Evaporite karst in three interior layered deposits in Iani Chaos, Mars. Geomorphology, 245: 15-22. https://doi.org/10.1016/j.geomorph.2015.05.018

Baioni D. \& Tramontana M. 2016 - Possible karst landforms in two unnamed craters in Tyrrhena Terra, Mars. Planetary and Space Science, 132: 57-65.

https://doi.org/10.1016/j.pss.2016.08.011

Boston P., 2004 - Extraterrestrial caves. In: Gunn J. (Ed.), Encyclopedia of caves and karst science. Fitzroy Dearborn, New York, p. 355-357.

Bibring J.P., Langevin Y., Mustard J.F., Poulet F., Arvidson R., Gendrin A., Gondet B., Mangold N., Pinet P., Forget F., \& the OMEGA team, 2006 - Global Mineralogical and Aqueous Mars History Derived from OMEGA/Mars Express Data. Science, 312: 400-404.

https://doi.org/10.1126/science.1122659

Bondesan A., Meneghel M. \& Sauro U., 1992 Morphometric analysis of doline. International Journal of Speleology, 21 (1-4): 1-55.

https://doi.org/10.5038/1827-806X.21.1.1

Brinkmann R., Parise M. \& Dye D., 2008 - Sinkhole distribution in a rapidly developing urban environment: Hillsborough County, Tampa Bay area, Florida. Engineering Geology, 99: 169-184.

https://doi.org/10.1016/j.enggeo.2007.11.020

Catling D.C., Wood S.E., Leovy C., Montgomery D.R., Greenberg H.M., Glein C.R. \& Moore J.M., 2006 - Light toned layered deposits in Juventae Chasma, Mars. Icarus, 181: 26-51.

https://doi.org/10.1016/j.icarus.2005.10.020

Chapman M.G., Gudmundsson M.T., Russel A.J. \& Hare T.M., 2003 - Possible Juventae Chasma subice volcanic eruptions and Maja Valles ice outburst floods on Mars: Implications of Mars Global Surveyor crater densities, geomorphology and topography. Journal of Geophysical Research, 108 (E10): 5113.

https://doi.org/10.1029/2002JE002009

Cooper A.H., 1989 - Airborne multispectral scanning of subsidence caused by Permian gypsum dissolution at Ripon, North Yorkshire. Quarterly Journal of Engineering Geology, 22: 219-229. https://doi.org/10.1144/GSL.QJEG.1989.022.03.06

Coooper A.H. \& Waltham A.C., 1989 - Subsidence caused by gypsum dissolution at Ripon, North Yorkshire. Quarterly Journal of Engineering Geology, 32: 305-310.

https://doi.org/10.1144/GSL.QJEG.1999.032.P4.01

Costard F.M. \& Kargel J.S., 1995 - Outwash plains and thermokarst on Mars. Icarus, 114: 93-112.

https://doi.org/10.1006/icar.1995.1046

Craddock R.A., Maxwell T.A. \& Howard A.D., 1997 Crater morphometry and modification in the Sinus Sabaeus and Margaritifer Sinus region of Mars. Journal of Geophysical Research, 102 (E6): 13321-13340.

https://doi.org/10.1029/97JE01084

Craddock R.A., Ansan V., Howard A.D. \& Mangold N., 2008 - Crater modification processes in the aeolis region of Mars. 39 ${ }^{\text {th }}$ Lunar and Planetary Science Conference, Abstract \#1617.
Cucchi F. \& Zini L., 2003 - Gypsum karst of Zagros mountains (I.R. Iran). Acta Carsologica, 32 (1): 69-82. https://doi.org/10.3986/ac.v32i1.365

De Blasio F.V., 2011. Landslides in Valles Marineris (Mars): a possible role of basal lubrification by subsurface ice. Planetary and Space Science, 59: 1384-1392. https://doi.org/10.1016/j.pss.2011.04.015

Denizman C., 2003 - Morphometric and spatial distribution parmeters of karstic depressions, Lower Suwannee River Basin, Florida. Journal of Cave and Karst Studies, 65 (1): 29-35.

De Waele J., Plan L. \& Audra P., 2009 - Recent developments in surface and subsurface karst geomorphology: An introduction. Geomorphology, 106: $1-8$.

https://doi.org/10.1016/j.geomorph.2008.09.023

De Waele J., Gutierrez F., Parise M. \& Plan L., 2011 Geomorphology and natural hazards in karst areas: A review. Geomorphology, 134: 1-8.

https://doi.org/10.1016/j.geomorph.2011.08.001

Di Maggio C., Madonia G., Parise M. \& Vattano M., 2012 - Karst of Sicily and its conservation. Journal of Cave and Karst Studies, 74 (2): 157-172.

https://doi.org/10.4311/2011JCKS0209

Dundas C.M., Byrne S. \& McEeven A.S., 2015 - Modelling the development of Martian sublimation thermokarst landforms. Icarus, 262: 154-169.

https://doi.org/10.1016/j.icarus.2015.07.033

El Maarry M.R., Dohm J.M., Marzo G.A., Fergason R., Goetz E.H., Pack A. \& Markiewicz W.J., 2012 Searching for evidence of hydrothermal activity at Apollinaris Mons, Mars. Icarus, 217: 297-314.

https://doi.org/10.1016/j.icarus.2011.10.022

Ferrarese F., Macaluso T., Madonia G., Palmeri A. \& Sauro U., 2002 - Solution and recrystallisation processes and associated landforms in gypsum outcrops of Sicily. Geomorphology, 49: 25-43.

https://doi.org/10.1016/S0169-555X(02)00159-9

Flahaut J., Carter J., Poulet F., Bibring J.-P., van Westrenen W., Davies G.R. \& Murchie S.L., 2015 Embedded clays and sulfates in Meridiani Planum, Mars. Icarus, 248: 269-288.

https://doi.org/10.1016/j.icarus.2014.10.046

Ford D.C., 1998 - Principal features of evaporite karst in Canada. Geografia Fisica e Dinamica Quaternaria, 3: 11-19.

Ford D.C. \& Williams P., 2007 - Karst hydrogeology and geomorphology, $2^{\text {nd }}$ ed. Wiley \& Sons, West Sussex, 562 p. https://doi.org/10.1002/9781118684986

Forsberg-Taylor N.K., Howard A.D. \& Craddock R.A., 2004 - Crater degradation in the Martian highlands: Morphometric analysis of the Sinus Sabaeus region and simulation modeling suggest fluvial processes. Journal of Geophysical Research, 109 (E5): E05002.

https://doi.org/10.1029/2004JE002242

Galve J.P., Gutiérrez F., Lucha P., Bonachea J., Cendrero A., Gimeno M.J., Gutiérrez M., Pardo G., Remondo J. \& Sánchez J.A., 2009 - Sinkholes in the salt-bearing evaporite karst of the Ebro River valley upstream of Zaragoza city NE Spain. Geomorphological mapping and analysis as a basis for riskmanagement. Geomorphology, 108: 145-158.

https://doi.org/10.1016/j.geomorph.2008.12.018

Gourronc M., Bourgeois O., Megè D., Pochat S., Bultei B., Massè M., Le Deil L., Le Mouèlic S. \& Mercier D., 2014 - One million cubic kilometers of fossil ice in Valles Marineris: Relicts of a 3.5 Gy old glacial landsystem along the Martian equator. Geomorphology, 204: 235-255.

https://doi.org/10.1016/j.geomorph.2013.08.009 
Grindrod P.M. \& Balme M.R., 2010 - Groundwater processes in Hebes Chasma, Mars. Geophysical Research Letters, 37 (13): L13202. https://doi.org/10.1029/2010GL044122

Gutiérrez F., Johnson K. \& Cooper A., 2008 - Evaporite karst processes, landforms, and environmental problems. Environmental Geology, 53 (5): 935-936. https://doi.org/10.1007/s00254-007-0715-9

Hynek B.M., 2009 - Ancient equatorial ice on Mars? Nature Geoscience, 2: 169-170. https://doi.org/10.1038/ngeo448

Jackson M.P.A., Adams J.B., Dooley A.R. \& Montgomery D.R., 2011 - Modeling the collapse of Hebes Chasma, Valles Marineris, Mars. Geological Society of America Bulletin, 123 (7-8): 1596-1627. https://doi.org/10.1130/B30307.1

Johnson K.S., 1997 - Evaporite karst in the United States. Carbonates and Evaporites, 12 (1): 2-14. https:/ / doi.org/10.1007/BF03175797

Johnson K.S., 2008. Evaporite-karst problems and studies in the USA. Environmental Geology, 53: 937-943. https://doi.org/10.1007/s00254-007-0716-8

Kargel J.S., Dougherty A., Feldman W., Hogenboom D., Marion G., McCarthy C. \& Prieto-Ballesteros O., 2004 - Hydrated Salts: Dehydration, dissolution, and incongruent melting in terrestrial evaporites and at Meridiani Planum, Mars. American Geophysical Union, Fall Meeting 2004, Abstract P21A-0205.

Klimchouk A., 2004 - Evaporite karst. In: Gunn J. (Ed.), Encyclopedia of caves and karst science. Fitzroy Dearborn, New York, p. 343-347.

Kress A.M. \& Head J.W., 2008 - Ring-mold craters in lineated valley fill and lobate debris aprons on Mars: Evidence for subsurface glacial ice. Geophysical Research Letters, 35 (23): L23206.

https://doi.org/10.1029/2008GL035501

Kuznetsov I.V., Kuzmin R.O. \& Greeley R., 2005 - Windrelated erosion depressions within a small impact craters in Chryse and Elysium Planitia, Mars. 36 ${ }^{\text {th }}$ Lunar and Planetary Science Conference, Abstract \#1810.

Kuzmin R.O., Mironenko M.V. \& Evdokimova N.A., 2009 - Spectral and thermodynamic constraints on the existence of gypsum at the Juventae Chasma on Mars. Planetary and Space Science, 57: 975-981. https://doi.org/10.1016/j.pss.2008.12.008

Laskar J., Correia A.C.M., Gastineau M., Joutel F., Levrard B. \& Robutel P., 2004 - Long term evolution and chaotic diffusion of the insolation quantities of Mars. Icarus, 170: 343-364.

https://doi.org/10.1016/j.icarus.2004.04.005

López-Vicente M., Navas A. \& Machìn J., 2009 Geomorphic mapping in endorheic catchments in the Spanish Pyrenees: An integrated GIS analysis of karstic features. Geomorphology, 111: 38-47. https://doi.org/10.1016/j.geomorph.2008.03.014

Madeleine J.B., Forget F., Head J.W., Levrard B., Montmessin F. \& Millaur E., 2009 - Amazonian northern mid-latitude glaciation on Mars: A proposed climate scenario. Icarus, 203: 390-405. https://doi.org/10.1016/j.icarus.2009.04.037

Malin M.C., Bell III J.F., Cantor B.A., Caplinger M.A., Calvin W.M., Clancy R.T., Edgett K.S., Edwards L., Haberle R.M., James P.B., Lee S.W., Ravine M.A., Thomas P.C. \& Wolff M.L., 2007 - Context camera investigation on board the Mars Reconnaissance Orbiter. Journal of Geophysical Research, 112 (E5): E05S04. https://doi.org/10.1029/2006JE002808

Martinez J.D. \& Boehner R., 1997 - Sinkhole in glacial drift underlain by gypsum in Nova Scotia, Canada. Carbonates and Evaporites, 12 (1): 84-90.

https://doi.org/10.1007/BF03175806
McEven A.S., Eliason E.M., Bergstrom J.W., Bridges N.T., Hansen C.J., Delamere W.A., Grant J.A., Gulick V.C., Herkenhoff K.E., Keszthelyi L., Kirk R.L., Mellon M.T., Squyres S.W., Thomas N. \& Weitz C.M., 2007 Mars reconnaissance Orbiter's High Resolution Imaging Science Experiment (HiRISE). Journal of Geophysical Research, 112 (E5): E05S02.

https://doi.org/10.1029/2005JE002605

McKay C.P., \& Nedell S.S., 1988 - Are there carbonate deposits in Valles Marineris, Mars? Icarus, 73: 142-148. https://doi.org/10.1016/0019-1035(88)90088-7

Mellon M.T., Feldman W.C., Hansen C.J., Arvidson R.E. \& Sizemore H.G., 2014 - Ground-ice extremes in martian permafrost as revealed by periglacial landforms. $8^{\text {th }}$ International Conference on Mars, Abstract \#1106.

Murchie S., Arvidson R., Bedini P., Beisser K., Bibring J.-P., Bishop J., Boldt J., Cavender P., Choo T., Clancy R.T., Darlington E.H., Des Marais D., Espiritu R., Fort D., Green R., Guinness E., Hayes J., Hash C., Heffernan K., Hemmler J., Heyler G., Humm D., Hutcheson J., Izenberg, N., Lee R., Lees J., Lohr D., Malaret E., Martin T., McGovern J.A., McGuire P., Morris R., Mustard J., Pelkey S., Rhodes E., Robinson M., Roush T., Schaefer E., Seagrave G., Seelos F., Silverglate P., Slavney S., Smith M., Shyong W.-J., Strohbehn K., Taylor H., Thompson P., Tossman B., Wirzburger M. \& Wolff M., 2007 - Compact Reconnaissance Imaging Spectrometer for Mars (CRISM) on Mars Reconnaissance Orbiter (MRO). Journal of Geophysical Research, 112 (E5): E05S03.

https://doi.org/10.1029/2006JE002682

Neuendorf K.K.E., Mehl J.P. \& Jackson J.A., (Eds), 2006 - Glossary of Geology. American Geological Institute, Alexandria, Virginia.

Noel A., Bishop J.L., Al-Samir M., Gross C., Flahaut J., McGuire P., Weitz C.M., Seelos F. \& Murchie S., 2015 - Mineralogy, morphology and stratigraphy of the lighttoned interior layered deposits at Juventae Chasma. Icarus, 251: 315-331.

https://doi.org/10.1016/j.icarus.2014.09.033

Novakovic N., Fueten F., Flahaut J., Stesky R., Rossi A.P. \& Hauber E., 2013 - Layer Attitude and Thickness Measurements of the three Interior Layered Deposits Mounds within Juventae Chasma, Mars. $44^{\text {th }}$ Lunar and Planetary Science Conference, Paper \#1068.

Ogawa Y., Yamagishi Y. \& Kurita K., 2003 - Evaluation of melting process of the permafrost on Mars: Its implication for surface features. Journal of Geophysical Research, 108 (E4): 8046.

https://doi.org/10.1029/2002JE001886

Pacifici A., Komatsu G. \& Pondrelli M., 2009 - Geological evolution of Ares Vallis on Mars: Formation by multiple events of catastrophic flooding, glacial and periglacial processes. Icarus, 202 (1): 60-77.

https://doi.org/10.1016/j.icarus.2009.02.029

Peulvast, J.P. \& Masson, P.L., 1993 - Erosion and tectonics in central Valles Marineris (Mars): A new morphostructural model. Earth, Moon, and Planets, 61: 191-217.

Preuschmann S., Benkkert D., Wagner R., Neukum G. \& the HRSC Co-Investigator Team, 2006 - Karstlike topography within the Ganges Chasma region. Geophysical Research Abstract, 8: 09383.

Robbins S.J. \& Hynek B.M., 2012 - A new global database of Mars impact craters $\geq 1 \mathrm{~km}: 2$. Global crater properties and regional variations of the simple-tocomplex transition diameter. Journal of Geophysical Research, 117 (E6): E06001. https://doi.org/10.1029/2011je003967 
Schaeffer M., 1990 - Geochemical evolution of the northern plains of Mars: Early hydrosphere, carbonate development and present morphology. Journal of Geophysical Research, 95 (B9): 14291-14300. https://doi.org/10.1029/JB095iB09p14291

Shean D.E., 2010 - Candidate ice-rich material within equatorial craters on Mars. Geophysical Research Letters, 37 (24): L24202. https://doi.org/10.1029/2010GL045181

Soare R.J., Kargel J.S., Osinski G.R. \& Costard F., 2007 Thermokarst processes and the origin of crater-rim gullies in Utopia and western Elysium Planitia. Icarus, 191: 95112. https://doi.org/10.1016/j.icarus.2007.04.018

Soare R.L., Conway S.J. \& Dohm J.M., 2014 - Possible ice-wedge polygons and recent landscape modification by "wet"periglacial processes in and around the Argyre impact basin, Mars. Icarus, 233: 214-228.

https://doi.org/10.1016/j.icarus.2014.01.034

Spencer J.R. \& Fanale P.F., 1990 - New models for the origin of Valles Marineris closed depressions. Journal of Geophysical Research, 95 (B9): 14301-14313. https://doi.org/10.1029/JB095iB09p14301
Telbisz T., Latos T., Deak M., Szekely B., Koma Z.\& Standovar T., 2016 - The advantage of lidar digital terrain models in doline morphometry compared to topographic map based dataset - Aggtelek karst (Hungary) as expample. Acta Carsologica, 45 (1): 5-18. https://doi.org/10.3986/ac.v45i1.4138

Wezel F.C. \& Baioni D., 2010 - Evidence for subaqueously resedimented sulphate evaporites on Mars. Planetary and Space Science, 58: 1500-1505.

https://doi.org/10.1016/j.pss.2010.07.003

Wyrick D., Ferri, D.A., Morris A.P., Colton S.L. \& Sims D.W., 2004 - Distribution, morphology, and origin of Martian pit crates chains. Journal of Geophysical Research, 109 (E6): E06005.

https://doi.org/10.1029/2004JE002240

Wordsworth R., Forget F., Millour E., Head J.W., Madeleine J.-B. \& Charnay B., 2013 - Global modelling of the early Martian climate under a denser $\mathrm{CO}_{2}$ atmosphere: water cycle and ice evolution. Icarus, 222: 1-19.

https://doi.org/10.1016/j.icarus.2012.09.036 